\title{
CARACTERIZAÇÃO SOROLÓGICA E MOLECULAR DE ROTAVÍRUS DE SUÍNOS NA REGIÃO SUL DO BRASIL
}

\section{SEROLOGICAL AND MOLECULAR CHARACTERIZATION OF SWINE ROTAVIRUS FROM THE SOUTH REGION OF BRAZIL}

\author{
Suzana Silveira KROEFF \\ Orientador: Professor Dr. Yasuyoshi HAYASHI \\ Departamento de Patologia Básica - UFPR
}

\begin{abstract}
RESUMO
O objetivo do estudo foi realizar a caracterização sorológica e molecular em amostras de rotavírus suíno na região Sul do Brasil. Para sua realização, foram colhidas 167 amostras de fezes de suínos nas fases de maternidade e creche em 52 granjas de produção de suínos que apresentavam freqüentes casos de diarréia, em 14 municípios dos Estados do Rio Grande do Sul, Santa Catarina e Paraná, durante o período compreendido entre junho de 1995 e outubro de 1997. Todas as amostras foram submetidas a um ensaio imunoenzimático (ELISA) para a detecção de rotavírus do grupo A, das quais 59 (35,33\%) foram positivas. Por meio da eletroforese em gel de poliacrilamida (PAGE) foi possível revelar a existência de um único eletroferótipo de rotavírus suíno nas regiões estudadas. As amostras positivas foram testadas para a caracterização de subgrupo por meio de

um ELISA com anticorpos monoclonais (mAb-ELISA), onde 9 amostras foram específicas para o subgrupo II e 50 não reagiram para nenhum dos subgrupos, sendo classificadas como nãolnãoll. Para a caracterização de genótipos $G$ e P utilizou-se a técnica de transcrição reversa, seguida da reação em cadeia da polimerase (RT-PCR) com primers específicos para rotavírus de suínos, bovinos e humanos. As amostras foram caracterizadas como genótipos G3, G4, G5, G9, G10 e P[6], P[7] e misturas de $\mathrm{P}[6]+\mathrm{P}[7]$ no mesmo animal. Este estudo evidenciou a existência de diferentes genótipos de rotavírus suínos, circulando ao mesmo tempo em uma mesma região e ou em uma mesma granja, incluindo o genótipo G9 que até o último ano tinha sido encontrado somente em amostras humanas.
\end{abstract}

\begin{abstract}
The purpose of this study was to evaluate serological and molecular characterization of swine rotavirus from the South region of Brazil. For this, 167 swine fecal samples were obtained from 52 farms with historical of diarrhea during weaning and postweaning period. In 14 regions from Rio Grande do Sul, Santa Catarina and Paraná states between June 1995 and October 1997. All samples were tested in a enzyme-linked immunosorbent assay (ELISA) to detect group A rotavirus, where 59 (35.33\%) samples were positive. Poliacrilamide gel electrophoresis (PAGE) test was revealed only one electropherotype of swine rotavirus. Positive samples were tested in an ELISA using monoclonal

antibodies to characterize subgroup, where 9 samples were specific for subgroup II and 50 samples did not react for tested subgroups (nonl-nonlI). Rotavirus $\mathrm{G}$ and $\mathrm{P}$ genotypes were characterized by reverse transcription followed by polymerase chain reaction (RT-PCR) with specific primers for swine, bovine and human. Samples were defined as genotypes G3, G4, G5, G9 and G10. P genotype identified where P[6], P[7] and mixtures of P[6] and P[7] occurring simultaneously in the same animal. This study showed presence of different swine rotavirus genotypes circulating in same region and/or same farm, including G9 genotype, not yet described in swine samples.
\end{abstract}

